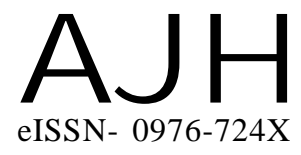

Received : 04.10.2017

Revised : 13.11 .2017

Accepted : 20.11.2017
Members of the Research Forum

Associated Authors:

${ }^{1}$ College of Horticulture,

MYSORE (KARNATAKA) INDIA

${ }^{2}$ College of Horticulture, BAGALKOT (KARNATAKA) INDIA

${ }^{3}$ University of Horticultural Sciences, Bagalkot, DYANAGIRI (KARNATAKA) INDIA
Author for correspondence :

V. P. SINGH

College of Horticulture,

BAGALKOT (KARNATAKA) INDIA

Email : vpsingh.neev@gmail.com
THEASIAN JOURNALOF HORTICULTURE

Volume 12 | Issue 2 | December, 2017 | 234-240

Visit us -www.researchjournal.co.in

\title{
Characterization of scented geranium accessions for odour and chemical compositions in southern transitional zone of Karnataka
}

\section{B.S. HARISH ${ }^{1}$, V. P. SINGH, Y.C. VISHWANATH ${ }^{2}$, H.T. SAKHUBAI ${ }^{3}$ AND} GANESH N. BHAT ${ }^{3}$

ABSTRACT : Scented geranium (Pelargonium spp.: Geraniaceae) is an important, high value aromatic crop of South African origin. Due to high demand and price for the oil, an excellent potential exists for increasing cultivated area in India. An attempt was made to evaluate and characterize the available accessions of scented geranium based on their physico-chemical properties, chemical composition and odour assessment of the oil. There were seven treatments and four replications. All the accessions possessed light yellow coloured oil except PG-10, which possessed light green colour. The oil from PG-10 showed maximum acid value (3.02). The oil from PG- 8 recorded the highest ester value (58.737). The oil form KB and CIMAP possessed maximum citronellol and geraniol content while, linalool was found to be maximum in case of PG-11. PG-10 contained maximum isomanthone (8.50\%). The oil from PG-1 recorded the highest citronellyl formate content (15.83\%). The essential oil was distilled during August from seven accessions upon GC analysis. The concentrations of isomenthone, citronellyl formate and citronellol were maximum in case of PF-10 (7.74, 23.18 and 37.07\%, respectively). The major alcohols i.e., citronellol, geraniol, linalool and nerol were maximum in case of the oils of $\mathrm{KB}$, CIMAP, PG-8 and PG-1 during May. Whereas, during August, PG-10 recorded the maximum nerol and cironellol whereas, PG-12 registered the highest concentration of geraniol and linalool. The rosy odour of different accessions is attributed to the presence of higher levels of geraniol, which is evident in the present case with the accession PG-12, during August. Hence, all the accessions differed significantly in all the parameters.

KEY WORDS : Geranium, Accessions, Physico-chemical properties, Chemical composition, Odour assessment

HOW TO CITE THIS ARTICLE : Harish, B.S., Singh, V. P., Vishwanath, Y.C., Sakhubai, H.T. and Bhat, Ganesh N. (2017). Characterization of scented geranium accessions for odour and chemical compositions in southern transitional zone of Karnataka. Asian J. Hort., 12(2) : 234-240, DOI : 10.15740/ HAS/TAJH/12.2/234-240. 